\title{
Concepção dos docentes acerca da inclusão de alunos com deficiência na Unochapecó
}

Franciane Barbieri Fiório

Silvia Maria Alves de Almeida

CADERNO DE RESUMOS

FisiSenectus. Unochapecó Ano 1 - Edição especial - 2013 p. 139

Franciane Barbieri Fiório, mestre em Engenharia Biomédica, docente do curso de Graduação em Fisioterapia da Universidade Comunitária da Região de Chapecó (Unochapecó), franci10@unochapeco.edu.br

\begin{abstract}
Resumo
Introdução: A inclusão escolar, no ensino fundamental, médio ou superior, deve ser entendida como um processo de adaptação mútua entre as pessoas com deficiência e toda a estrutura escolar, para que essas tenham um desenvolvimento pleno. E, para que haja sucesso no processo de ensino-aprendizagem, os professores devem estar preparados pedagogicamente para a prática inclusiva. Objetivo: Esta pesquisa teve como objetivo conhecer a concepção didático pedagógica de docentes do curso de Graduação em Fisioterapia da Unochapecó, bem como suas práticas docentes e desafios acerca da inclusão. Metodologia: Participaram da pesquisa dez professores do curso de fisioterapia da Unochapecó, os quais responderam um questionário com perguntas abertas acerca da inclusão de alunos com deficiência no ensino superior. Resultados: Os professores relataram que, apesar de terem alunos com deficiência em suas disciplinas, não estão preparados e nem receberam capacitação para ensinar esses alunos. Mesmo sem terem essa capacitação, realizam algumas adaptações metodológicas/curriculares para atender as necessidades do aluno com deficiência, como aumentar a letra dos slides e em provas para os alunos com deficiência visual tentar falar mais pausadamente para que o aluno com deficiência auditiva pudesse fazer leitura labial, além do suporte do intérprete de libras, mas que essas adaptações foram todas no empirismo, surgindo conforme as demandas. No entanto, relatam a grande dificuldade que têm em realizar uma avaliação condizente para se avaliar o processo de ensino-aprendizagem destes alunos. Conclusão: Constata-se, através desta pesquisa, que os maiores desafios dos professores é em relação ao processo de ensino-aprendizagem, necessitando de mais capacitação, principalmente em relação às práticas pedagógicas e para isso é necessário o suporte por parte da instituição de ensino para garantir a qualidade nas práticas inclusivas.
\end{abstract}

\section{Palavras-chave}

Educação. Inclusão. Ensino superior. 